\title{
Reproductive Biotechnologies in Indian Cattle
}

\section{Purohit GN*}

Department of Veterinary Gynecology and Obstetrics, Rajasthan University of Veterinary and Animal Sciences, India

*Corresponding author: Purohit GN, Department of Veterinary Gynecology and

\section{Mini Review}

Volume 3 Issue 1

Received Date: December 09, 2017

Published Date: March 13, 2018

Obstetrics, College of Veterinary and Animal Sciences, Rajasthan University of Veterinary and Animal Sciences, Bikaner Rajasthan India, Email: gnpobs@gmail.com

\section{Abstract}

In recent years there have been immense improvements in application of reproductive biotechnologies in cattle and include artificial insemination, embryo transfer, ovum pick up and in vitro fertilization, semen sexing, cloning, transgenics and xenotransplantation. The purpose of these technologies had been improvement of the genetics of animals or producing animals of benefit to human beings. The application of these technologies in indigenous dairy cows of India had been slow. This manuscript describes the status of some of the reproductive biotechnologies as applied to Indian breeds of cows.

Keywords: Reproductive Biotechnologies; Crossbreeding; Embryo Transfer; Transgenics; Xenotransplantation

Abbreviations: AI: Artificial insemination; FSDs: Frozen Semen Doses; NMBP: National Mission on Bovine Productivity; ETT: Embryo Transfer Technology; OPU: Ovum Pick up; SCNT: Somatic cell nuclear transfer

\section{Artificial Insemination}

Artificial insemination (AI) is the single most important reproductive biotechnology which had the highest impact in breed improvement of dairy cows and other livestock species [1]. In India AI was introduced in the early forties and Dr Sampat Kumaran is considered to have performed the first AI at Mysore palace dairy farm. The focus of AI had been crossbreeding with exotic breeds however; currently stress is being given to the conservation of indigenous breeds. As per Animal Husbandary Department Govt. of India Annual report 2016-17 there are presently 49, ISO certified (A and B Graded) Semen Stations in India producing around 95 million Frozen
Semen Doses (FSDs) to cater the need of Artificial Insemination in the country. Currently frozen semen of Gir, Kankrej, Sahiwal, Khillar, Red Sindhi, Rathi, Tharparkar, Haryana, Deoni, Amritmahal, Hallikar is available through various sperm stations in India. The Animal husbandry department initiated the Rashtriya Gokul mission since 2014 for conservation and development of indigenous breeds of livestock in India. The 2 important objectives of this mission are upgradation of nondescript cattle using elite indigenous breeds like Gir, Sahiwal, Rathi, Deoni, Tharparkar, Red Sindhi and distribution of disease free high genetic merit bulls for natural service.

National Mission on Bovine Productivity (NMBP) will be implemented with following four components:

(i)Pashu Sanjivni: an Animal Wellness Programme encompassing provision of Animal Health cards (Nakul Swasthya Patra) along with UID identification and uploading data on National Data Base. 
(ii) Advanced breeding Technology: including Assisted Reproductive Techniques- IVF/MOET and sex sorted semen technique to improve availability of disease free high genetic merit female bovines.

(iii) Creation of "E-Pashu Haat" an e-market portal for bovine germplasm for connecting breeders and farmers.

(iv) National Bovine Genomic Centre for Indigenous Breeds (NBGC-IB).

In spite of the benefits of $\mathrm{AI}$ and the steps undertaken by the Govt in promotion of AI adoption by farmers had been slow. In a recent study involving farmers in 4 North Indian states (UP, Uttarakhand, Haryana and Punjab) it was shown that full adoption of AI as a means of breeding was low $3.33 \%, 7.77 \%, 24.44 \%$ and $62.3 \%$ respectively in the four states under study [2]. The distance to veterinary institutions and poor education of the farmers were the important hurdles to the adoption of AI in this study suggesting stress on opening of more AI centers and farmers education. The maintenance of semen and proper timing of insemination are other two important determinants of success of AI. In order to promote AI using indigenous breeds semen efforts have to be made in selecting outstanding bulls from these breeds.

\section{Multiple Ovulation and Embryo Transfer}

Embryo transfer is a technique that can greatly increase the number of offspring that a genetically important cow can produce. Embryo transfer technology
(ETT) has emerged as an important tool to improve livestock at faster rate, as in this technique, genetic contribution of both the male and female are utilized simultaneously. Thus, the most important application of ETT is the production of A1 bulls from the best proven bulls and cows available [3]. Other applications of ETT include genetic evaluation through sibling testing, conservation and preservation of the endangered breeds, creation of disease free herd, economic transport of livestock, salvage of reproductive function, production of progeny of desired sex, production of identical twins and clones and genetic modification of animals [3].

The in vivo embryo production involves superovulation of donors using ECG or FSH and recovery of embryos using non-surgical approaches. The embryos are then transferred to synchronized recipients to establish pregnancies. A large number of variables determine the ovulatory responses of cattle to super stimulation using FSH.

The first embryo transfer calf in India was born in 1987 at National Institute of Immunology New Delhi [4]. There has been a lot of work on super ovulation and embryo transfer in indigenous breeds of cows (Table 1) however; we still have to do a lot more. Problems associated with embryo transfer in indigenous cows involve those associated with embryo transfer in general and those specific to the breed for example the problems of cervical hypertrophy and fibrosis in Rathi cows limiting the passage of catheter for embryo recovery or transfer.

\begin{tabular}{|c|c|c|c|c|}
\hline Breed & Mean CL & Mean TE & Mean VE & Reference \\
\hline Sahiwal & $9.16 \pm 4.41$ & - & $5.33 \pm 4.19$ & Mishra, et al. (1997) [5] \\
\hline Sahiwal & - & $2.33 \pm 0.76$ & $1.13 \pm 0.42$ & Prasad, et al. (2003) [6] \\
\hline Ongole & $9.09 \pm 0.40$ & $5.57 \pm 0.36$ & $1.79 \pm 0.28$ & Kasiraj, et al. (2000) [7] \\
\hline Kankrej & - & 6.7 & 2.9 & SAG 1996-97 [8] \\
\hline $\begin{array}{c}\text { Rathi and its } \\
\text { crossbred (eCG) }\end{array}$ & $7.92 \pm 0.66$ & $3.96 \pm 0.49$ & - & Purohit, et al. (2000) [9] \\
\hline $\begin{array}{c}\text { Rathi and } \\
\text { crossbred (FSH) }\end{array}$ & $7.24 \pm 0.52$ & $5.97 \pm 0.56$ & - & Purohit, et al. (2000) [9] \\
\hline Sahiwal & 10.5 & 9 & - & Singhal, et al. (2017) [10] \\
\hline Panganur & $5.29-8.14$ & $1.14-2.57$ & - & Veerbramhaiah, et al. (2012) [11] \\
\hline $\begin{array}{l}\text { Red Sindhi (one } \\
\text { cow) }\end{array}$ & & $\begin{array}{l}16 \text { embryos } \\
\text { recovered }\end{array}$ & $\begin{array}{l}13 \text { were transferable } \\
\text { grade }\end{array}$ & Rangasamy, et al. (2015) [12] \\
\hline Vechur & - & 5.5 & 4.9 & Venkatachalapathy, et al. (2000) [13] \\
\hline
\end{tabular}

Table 1: Superovulatory response and embryo recovery in different breeds of cattle 


\section{Open Access Journal of Veterinary Science \& Research}

\section{Invitro Embryo Production}

In vitro embryo production involves the maturation of oocytes retrieved from live donors by OPU, their maturation and fertilization in vitro and development to blastocysts and transfer to recipients. Many reports have appeared on the in vitro maturation, fertilization and development of abattoir derived oocytes to blastocysts however, the benefit of in vitro embryo production lies in retrieval of oocytes from donors of known genetic merit. This involves the retrieval of oocytes by ultrasound guided ovum pick up (OPU) from live animals. The procedures of OPU retrieve oocytes from prospective donors without disturbing their physiology. However, the rate of blastocyst formation (30-60\%) and calf production $(10-15 \%)$ is low by in vitro procedures. Moreover, the viability of in vitro produced embryos is poor compared to in vivo developed embryos. Many reports on in vitro embryo production from abattoir derived embryos have appeared in India [14]. However reports on production of live calves from OPU-IVF derived embryos are scarce. The NDRI website shows that the first OPU-IVF Sahiwal calf was produced at NDRI in 2007. OPU derived Sahiwal oocytes were matured in vitro to yield blastocysts in one study [15]. A recent report at the website http://www.asianage.com/metros/mumbai/ mentions that the first IVF derived embryo produced from a Tharparkar cow oocyte and sperm derived from bull of the same species and placed in the uterus of a Jersey cow was born on $5^{\text {th }}$ September 2017 in Pune by efforts of $\mathrm{Dr}$ Zawar. Hence the techniques of OPU/IVF produced calves in Indian breeds of cattle are still in infancy.

\section{Sexing of Semen}

The important discovery that female-determining ( $\mathrm{X}$ chromosome bearing) sperm had 3-4\% more DNA than male-determining (Y-chromosome bearing) sperm and when stained with fluorescent dye, X-chromosome bearing sperm glows more than Y-chromosome bearing sperm and facilitated separation of these sperm using flow cytometry [16], Thus, sperms with an or Y chromosome could be used to produce male or female embryos/animals [17]. The accuracy of this technique is high and sex of over $90 \%$ of the calves born correlated with the use of $\mathrm{X}$ or Y-chromosome bearing sperm rich fractions and the sexed semen is available commercially [18]. Sexed semen is currently available in many countries however there are still many limitations. ABS Technology at its website genusabsindia.com claims to make available sexed semen of Sahiwal, Gir and Red Sindhi bulls. A recent report mentioned the employment of cell sorters at Bengal and Kerala and production of live calves from sex sorted semen [19]. Also the use of sexed semen of exotic breeds is becoming popular in some Indian states like Punjab, Haryana, Kerala and West Bengal [19]. However the high cost and poor pregnancy rates are the limiting factors that have prevented the wider use of sexed semen.

\section{Somatic Cell Nuclear Transfer}

Somatic cell nuclear transfer (SCNT) is a powerful technique and potentially it could be used for the multiplication of desired animals, minimizing the genetic variation in the experimental animals, production of animal models, genetically modified farm animals to make modification o f milk, growth, disease resistance, xenotransplantation etc. SCNT may be used for conservation and propagation of endangered species which are at the verge of extinction such as Cheetah, one horned rhinoceros, swamp deer, hispid hare, wild buffalo, Assam root turtle, pigmy hog etc. in India. Recently, the SCNT has emerged as a tool for production of stem cells for therapeutic purposes, popularly known as 'Therapeutic Cloning'. The efficiency of SCNT is, however, still extremely low (Dolly was one from 277 attempts) for unknown reasons [20].

\section{References}

1. Choudhary KK, Kavya KM, Jerome A, Sharma SK (2016) Advances in reproductive biotechnologies. Vet World 9(4): 388-395.

2. Rathod P, Chander M, Chetan Sharma G (2017) Adoption status of artificial insemination in Indian dairy sector: application of multinomial logit model. J Appl Anim Res 45(1): 442-446.

3. Mishra OP, Khan J R, Awasthi MK (2002) Estrus synchronization with cloprostenol and effect of Follitropin treatment on superovulatory response and embryo recovery in Sahiwal Cows. Indian J Anim Reprod 23(2): 193-195.

4. Raghupathy R, Hasnain SE (1991) Basic and biomedical-product oriented research-the National Institute of Immunology. Current Sci 60: 528-533.

5. Mishra UK, Mishra P, Khan JR (1997) Effect of repeated superovulation on superovulatoly response and embryo recovey in Sahiwal cows. Indian J Anim Reprod 18(1): 8-10.

6. Prasnd Shiv, Matlrya SN, Varshney VP (2003) Serum progesterone and estradiol $17 \mathrm{~b}$ concentration in relation to superovulatory response in embryo donor 


\section{Open Access Journal of Veterinary Science \& Research}

(Sahiwal) and conception rate in embryo recipient (crossbred) cattle. Indian J Anim Sci 73(4): 353-356.

7. Kasiraj R, Rao MM, Reddy NSR, Misra AK, Pant H C (2000) Superovulation and embryo recovery in Ongole cows using FSH or equine chorionic gonadotrophin. Indian J Anim Sci 70(3): 251-253.

8. Sabarmati Ashram Gaushala (1996-97) Annual report.

9. Purohit GN, Datt M, Sharma SS (2000) Embryo recovery to different superovulatory regimens and live birth subsequent to non-surgical embryo transfer in Rathi and its crossbred cows. Indian J Anim Sci 70(10): 1064-1066.

10. Singhal S, Singh N, Malik VS, Kumar AA, Brar PS (2017) Preliminary study on super's stimulatory response using low dose FSH and subsequent embryo transfer in Sahiwal cattle during summer season. Indian J Anim Reprod 38(2): 37-39.

11. Veerbramhaiah K, Rao VH, Naidu KV (2012) Superovulatory response in endangered Panganur cows with FSH-p. Tamil Nadu J Vet Anim Sci 8(4): 241-244.

12. Rangasamy S, Sridevi P, Saravanam D, Sarath T (2015) A rare incidence of high superovulatory response and embryo recovery in a Red Sindhi cow and its conception rate. Indian Vet J 92(5): 78-79.

13. Venkatachalapathy RT, Jayachandran D, Venugopal VS, Sosamma Iype, Iype S (2000) Multiple ovulation embryo transfer for conserving Vechur cattle of Kerala. Indian J Anim Sci 70(8): 833-834.

14. Suthar VS, Gandhi RG (2009) Bovine in vitro embryo production: An overview. Vet World 2(12): 478-479.

15. Verma PK (2005) Ultrasound guided transvaginal follicular aspiration and in-vitro embryo production in Sahiwal cows. M.V.Sc Thesis, G.B. Pant University of Agriculture \& Technology, Uttaranclial, India.

16. Johnson LA, Cran DG, Welch GR, Polge C (1996) Gender press election in mammals. Proceedings of XX Beltsville symposium. Biotechnologies role in genetic improvement of farm animals 151: 65.

17. Seidel GE, Schenk JL, Herickhoff LA, Doyle SP, Brink Z, et al. (1999) Insemination of heifers with sexed sperm. Theriogenology 52(8): 1407-1420.

18. Seidel GE (2003) Economics of selecting for sex: the most important genetic trait. Theriogenology 59(2): 585-598.

19. Kumar A, Vineeth MR, Sinha R, Singh RK, Thakur A, et al. (2016) Current status, scope and constraints of sexed semen-An Indian perspective. Agric Reviews 37(3): 240-244.

20. Renard JP, Zhou Qui, LeBourhis D, Chavattc-Palmer P, Hue Heyman Y, et al. (2002) Nuclear transfer technologies: between successes and doubts. Theriogenology 57(1): 203-227. 